\title{
Cytotoxic Deoxypodophyllotoxin Can Be Extracted in High Purity from Anthriscus sylvestris Roots by Supercritical Carbon Dioxide
}

Authors

Christel L. C. Seegers, Pieter G. Tepper, Rita Setroikromo, Wim J. Quax

Affiliation

Department of Chemical and Pharmaceutical Biology, Groningen Research Institute of Pharmacy, University of Groningen, Groningen, Netherlands

Key words

Anthriscus sylvestris, Apiaceae, deoxypodophyllotoxin, etoposide, supercritical carbon dioxide extraction

received August 7, 2017

revised November 10, 2017

accepted November 24, 2017

Bibliography

DOI https://doi.org/10.1055/s-0043-123938

Published online December 18, 2017 | Planta Med 2018; 84:

544-550 @ Georg Thieme Verlag KG Stuttgart · New York I

ISSN 0032-0943

Correspondence

Prof. Dr. Wim J. Quax

Department of Chemical and Pharmaceutical Biology,

Groningen Research Institute of Pharmacy, University of

Groningen

Antonius Deusinglaan 1, 9713 AV Groningen, Netherlands

Phone: + 31503632558 , Fax: + 3150363000

w.j.quax@rug.nl $\bigoplus \begin{aligned} & \text { Supporting information available online at } \\ & \text { http://www.thieme-connect.de/products }\end{aligned}$

\begin{abstract}
Deoxypodophyllotoxin is present in the roots of Anthriscus sylvestris. This compound is cytotoxic on its own, but it can also be converted into podophyllotoxin, which is in high demand as a precursor for the important anticancer drugs etoposide and teniposide. In this study, deoxypodophyllotoxin is extracted from $A$. sylvestris roots by supercritical carbon dioxide extraction. The process is simple and scalable. The supercritical carbon dioxide method extracts $75-80 \%$ of the total deoxypodophyllotoxin content, which is comparable to a single extraction by traditional Soxhlet. However, less polar components are extracted. The activity of the supercritical carbon dioxide extract containing deoxypodophyllotoxin was assessed by demonstrating that the extract arrests A549 and HeLa cells in the $\mathrm{G}_{2} / \mathrm{M}$ phase of the cell cycle. We conclude that biologically active deoxypodophyllotoxin can be extracted from A. sylvestris by supercritical carbon dioxide extraction. The method is solvent free and more sustainable compared to traditional methods.
\end{abstract}

\section{ABBREVIATIONS \\ DPT deoxypodophyllotoxin \\ FACS fluorescence-activated cell sorting \\ $\mathrm{SC}-\mathrm{CO}_{2}$ supercritical carbon dioxide}

\section{Introduction}

Podophyllotoxin, which serves as the precursor of several pharmaceutically important antitumor drugs like etoposide and teniposide ( $\triangleright$ Fig. 1), is extracted from the roots of Podophyllum hexandrum, native to the Himalayan area. Overharvesting has led to the listing of $P$. hexandrum on the Convention on International Trade in Endangered Species of Wild Fauna and Flora list [1]. Therefore, an alternative source for podophyllotoxin has to be found. The lignan
DPT can be extracted from the roots of Anthriscus sylvestris (L.) Hoffm. (Apiaceae). This common wild plant grows in Europa and temperate Asia, and is considered an invasive species in the Netherlands, Sweden, and Iceland [2-4]. DPT has higher cytotoxicity than podophyllotoxin [5], but it has never been in clinical development. DPT can be converted into epipodophyllotoxin by insertion of a hydroxyl group using cytochrome P450 3A4 produced in Escherichia coli [6] or via chemical synthesis [7]. The resulting epipodophyllotoxin can be easily converted into etoposide [6]. Therefore, A. sylvestris might become an alternative source to $P$. hexandrum for the production of etoposide.

DPT has been extracted previously by Soxhlet [8], and by sonication [9] for small-scale analysis of the DPT content in A. sylvestris. Both methods are strongly dependent on the use of organic solvents, such as methanol. The hazardous nature, high costs, and environmental risks of organic solvent extraction led to the quest for alternative extraction techniques [10]. Green chemistry ap- 
proaches are aimed at the reduction or elimination of organic solvent usage in extraction techniques. A "greener" alternative is supercritical fluid extraction [11]. The most popular fluid for supercritical extraction is carbon dioxide, as it is nonflammable, nontoxic, easily available, and cheap. Furthermore, supercritical conditions are reached at a relatively low pressure (73 bar) and temperature $\left(3^{\circ} \mathrm{C}\right)[12,13]$. SC- $\mathrm{CO}_{2}$ extraction can be used to selectively extract compounds, as the solubility of components can be manipulated by changing the pressure and/or temperature [12]. SC- $\mathrm{CO}_{2}$ extraction has already been applied for the extraction of lignans from the seeds, fruits, and stems of Schizandra chinensis $[14,15]$. However, extracting a high yield of lignans from the leaves was only possible by the addition of the cosolvent ethanol [14]. Furthermore, Gupta and coworkers extracted podophyllotoxin from $P$. hexandrum roots using $\mathrm{SC}-\mathrm{CO}_{2}$ extraction and the cosolvents ethyl acetate and methanol [16].

This study focuses on the feasibility of using $\mathrm{SC}-\mathrm{CO}_{2}$, without the addition of organic cosolvents, for the extraction of biologically active DPT from $A$. sylvestris populations in the wild. Furthermore, a novel quick methanol vortex extraction method for analytical determination of the DPT content in A. sylvestris roots is provided.

\section{Results and Discussion}

An initial experiment showed that DPT can be extracted in the absence of solvents from $A$. sylvestris by $\mathrm{SC}-\mathrm{CO}_{2}$. Subsequently, the parameters for supercritical carbon dioxide as described in the Methods section were altered in a systematic fashion to investigate the most efficient extraction of DPT from A. sylvestris roots. A factorial design approach was deployed to find the combination with the highest DPT yield. DPT yields at a pressure of 175 bar were $20 \%$ higher than at 100 bar and more reproducible than at 250 bar. Therefore, 175 bar was set as the standard. Extractions for $1 \mathrm{~h}$ at 40,60 , and $80^{\circ} \mathrm{C}$ yielded comparable amounts of DPT ( $\vee$ Fig. 2). In total, $1.6 \pm 0.3 \mathrm{mg} / \mathrm{g}$ DPT was extracted at $40^{\circ} \mathrm{C}$, $2.0 \pm 0.3 \mathrm{mg} / \mathrm{g}$ at $60^{\circ} \mathrm{C}$, and $1.7 \pm 0.3 \mathrm{mg} / \mathrm{g}$ at $80^{\circ} \mathrm{C}$. To test for residual DPT in the plant material after extraction at $60^{\circ} \mathrm{C}$, a sequential extraction on the same plant residue was performed by $\mathrm{SC}-\mathrm{CO}_{2}\left(1 \mathrm{~h}\right.$ at $\left.60^{\circ} \mathrm{C}\right)$, followed by Soxhlet extraction $(2 \times 1 \mathrm{~h})$. The SC $-\mathrm{CO}_{2}$ extraction yielded an additional $0.5 \pm 0.1 \mathrm{mg} / \mathrm{g}$ and the Soxhlet extraction $0.7 \pm 0.06 \mathrm{mg} / \mathrm{g}$ (Fig. 1S, Supporting Information). Therefore, we calculate that $2.5 \pm 0.4 \mathrm{mg} / \mathrm{g}$ DPT was extracted at $60^{\circ} \mathrm{C}$ after $2 \times 1 \mathrm{~h}$ extraction at 175 bar by SC-CO . Approximately $20-25 \%$ of DPT remains in the plant material, which can be extracted by Soxhlet extraction. The presence of DPT in the extracts was confirmed by LC-ESI-MS/MS analysis (fragment ions of $m / z 231$ and $m / z$ 187) [17].

The next question was whether the $\mathrm{SC}-\mathrm{CO}_{2}$ extract from A. sylvestris was biologically active. DPT binds to tubulin and prevents microtubule assembly resulting in cell cycle arrest at the $\mathrm{G}_{2} / \mathrm{M}$ phase, which can be analyzed by FACS analysis of propidium iodide-stained cells [18]. We treated lung epithelial cells (A549) and cervix epithelial cells (HeLa) with $\mathrm{SC}-\mathrm{CO}_{2}$ extract, pure A. sylvestris DPT, and etoposide (a DPT-derived drug). Etoposide blocks the cell cycle in the late $S$ or early $G 2$ phase of the cell cycles by inhibition of DNA topoisomerase II [19], and is used, for

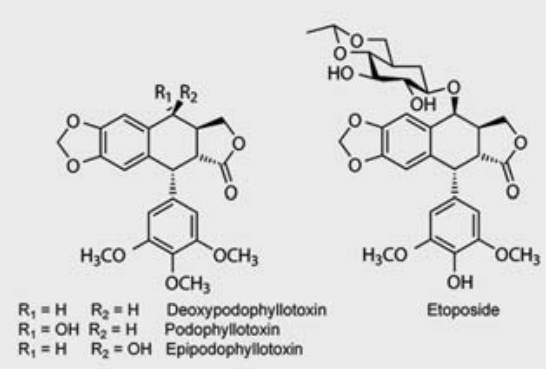

- Fig. 1 Chemical structures of deoxypodophyllotoxin, podophyllotoxin, epipodophyllotoxin, and etoposide.

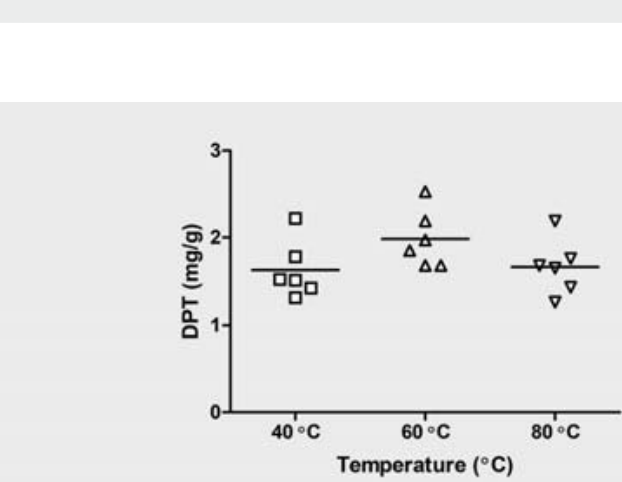

- Fig. 2 Extraction yields of deoxypodophyllotoxin (DPT) by SC- $\mathrm{CO}_{2}$ extraction. A. sylvestris roots were extracted at 175 bar for $1 \mathrm{~h}$ at $40^{\circ} \mathrm{C}(\square), 60^{\circ} \mathrm{C}(\triangle)$, or $80^{\circ} \mathrm{C}(\nabla)$. The values have been corrected for dilutions and calculated back to dry weight of the initial plants $(n=6)$.

example, in the treatment of small lung cancer [20]. After $24 \mathrm{~h}$ treatment, SC- $\mathrm{CO}_{2}$ extract containing $0.5 \mu \mathrm{M}$ DPT increased the percentage of cells in the $\mathrm{G}_{2} / \mathrm{M}$ phase from 9.4 to $70.4 \%$ in $\mathrm{A} 549$ cells ( $\triangleright$ Fig. 3 ). This increase is comparable to the one obtained with $0.5 \mu \mathrm{M}$ pure DPT $(70.7 \%)$, confirming that the extracted DPT is active ( $\triangleright$ Fig. 4 ). It is noteworthy that the effect of etoposide was less pronounced as the percentage of $G_{2} / M$ phase cells reached only $46.4 \%$ after treatment with the high concentration of $10 \mu \mathrm{M}$ etoposide ( $\triangleright$ Fig. 4). The same trend was observed for HeLa cells (Fig. 2S, Supporting Information). These findings show that extract from SC- $\mathrm{CO}_{2}$ extraction is capable of arresting cells in the $\mathrm{G}_{2} / \mathrm{M}$ phase of the cell cycle in a dose-dependent manner that correlates well with the dose-response curve of pure DPT. This suggests that DPT accounts for the cytotoxic activity of the $\mathrm{SC}-\mathrm{CO}_{2}$ extract, which is in concert with the findings using methanolic extracts of $A$. sylvestris [18]. The high activity on cell cycle arrest by pure DPT is in accordance to literature values [18,21]. Interestingly, at similar concentrations, the clinically used etoposide was much less potent in obtaining arrest in the $\mathrm{G}_{2} / \mathrm{M}$ phase. The difference in the action mechanism, topoisomerase inhibition for etoposide versus tubulin destabilization for DPT, might be responsible for this [22].

In order to assess the new extraction method, we have compared (i) the solvent-free $\mathrm{SC}-\mathrm{CO}_{2}$ extraction method to (ii) the 



- Fig. 3 Cell cycle arrest of A549 cells treated with SC- $\mathrm{CO}_{2}$ extract. A549 cells were treated with SC- $\mathrm{CO}_{2}$ extract containing 0 (A), 0.1 (B), or $0.5 \mu \mathrm{M}$ (C) deoxypodophyllotoxin for $24 \mathrm{~h}$. FACS was used as the method of analysis.

Soxhlet, (iii) a methanol vortex extraction, and (iv) a sonication method. The DPT absolute yields for the $\mathrm{SC}-\mathrm{CO}_{2}$ method were compared to the other methods ( $\bullet$ Fig. 5 ). As mentioned earlier, the yield of $\mathrm{SC}-\mathrm{CO}_{2}$ extraction at 175 bar after $2 \times 1 \mathrm{~h}$ is $2.5 \pm$ $0.4 \mathrm{mg} / \mathrm{g}$ (i). DPT extracted by Soxhlet extraction (ii) yielded $3.2 \pm 0.5 \mathrm{mg} / \mathrm{g}$ after two rounds of extraction. The new analytical methanol vortex extraction method (iii) after extraction three times gave a yield of $2.8 \pm 0.3 \mathrm{mg} / \mathrm{g}$. Extraction by sonication (iv) yielded $3.1 \pm 0.4 \mathrm{mg} / \mathrm{g}$ DPT. An additional round of extraction did not result in higher yields for any of the methods. Significantly more DPT was extracted by Soxhlet ( $p$ value $=0.012$ ) and sonication ( $p$ value $=0.023$ ) than by SC- $\mathrm{CO}_{2}$ extraction. The yield of the methanol vortex extraction was not significantly different from the yields obtained with the other methods. Apart from absolute yield, we also looked at the cleanness of the HPLC profiles. Additional polar plant components were observed with the Soxhlet (ii) and methanol vortex methods (iii) (encircled peaks in > Fig. 6). These peaks were absent from the HPLC chromatogram of the $\mathrm{SC}-\mathrm{CO}_{2}$ (i) and sonication (iv) method. This study shows that DPT can be extracted from $A$. sylvestris by $\mathrm{SC}-\mathrm{CO}_{2}$ extraction in a reasonable yield, as around $75-80 \%$ of the DPT was recovered. Furthermore, the HPLC profile of the SC- $\mathrm{CO}_{2}$ extraction is cleaner than that of the Soxhlet extraction. This is caused by the absence of polar components, which will not be extracted by $\mathrm{SC}-\mathrm{CO}_{2}$ extraction and therefore remain in the plant residue. In contrast, these polar components are extracted in the Soxhlet and methanol vortex methods, as observed in the HPLC chromatograms where they are eluted with the front of the solvent peak. This suggests that the $\mathrm{SC}-\mathrm{CO}_{2}$ (i) and sonication (iv) methods could be more selective. Furthermore, the removal of $\mathrm{CO}_{2}$ in a gaseous state reduces the volume in further downstream processes. LCESI-MS/MS analysis confirmed the presence of six lignans in all of the extracts: isopicropodophyllone (1), podophyllotoxone (2), DPT (3), yatein (4), anhydropodorhizol (5), and angeloyl podophyllotoxin (6) ( $\triangleright$ Table 1, Fig. 6, and Fig. 3S, Supporting Information). Additionally, the compounds anthriscrusin (7), and



- Fig. 4 Cell cycle arrest of A549 cells in the $G_{2} / M$ phase after $24 \mathrm{~h}$ treatment. Cells were treated with SC- $\mathrm{CO}_{2}$ extract containing $0,0.1$, 0.5 , 1 , or $10 \mu \mathrm{M}$ deoxypodophyllotoxin (DPT), pure DPT, or etoposide $(n=1)$.



- Fig. 5 Comparison of deoxypodophyllotoxin (DPT) extraction yields by various extraction methods. The extraction yields of SC- $\mathrm{CO}_{2}(\triangle)$, Soxhlet $(\square)$, methanol vortex $(\mathrm{MeOH}, \nabla)$, and sonication $(O)$ were compared. The values have been corrected for dilutions and calculated back to dry weight of the initial plants $(n=6)$. $P$ value $<0.05$, Student's t-test. 

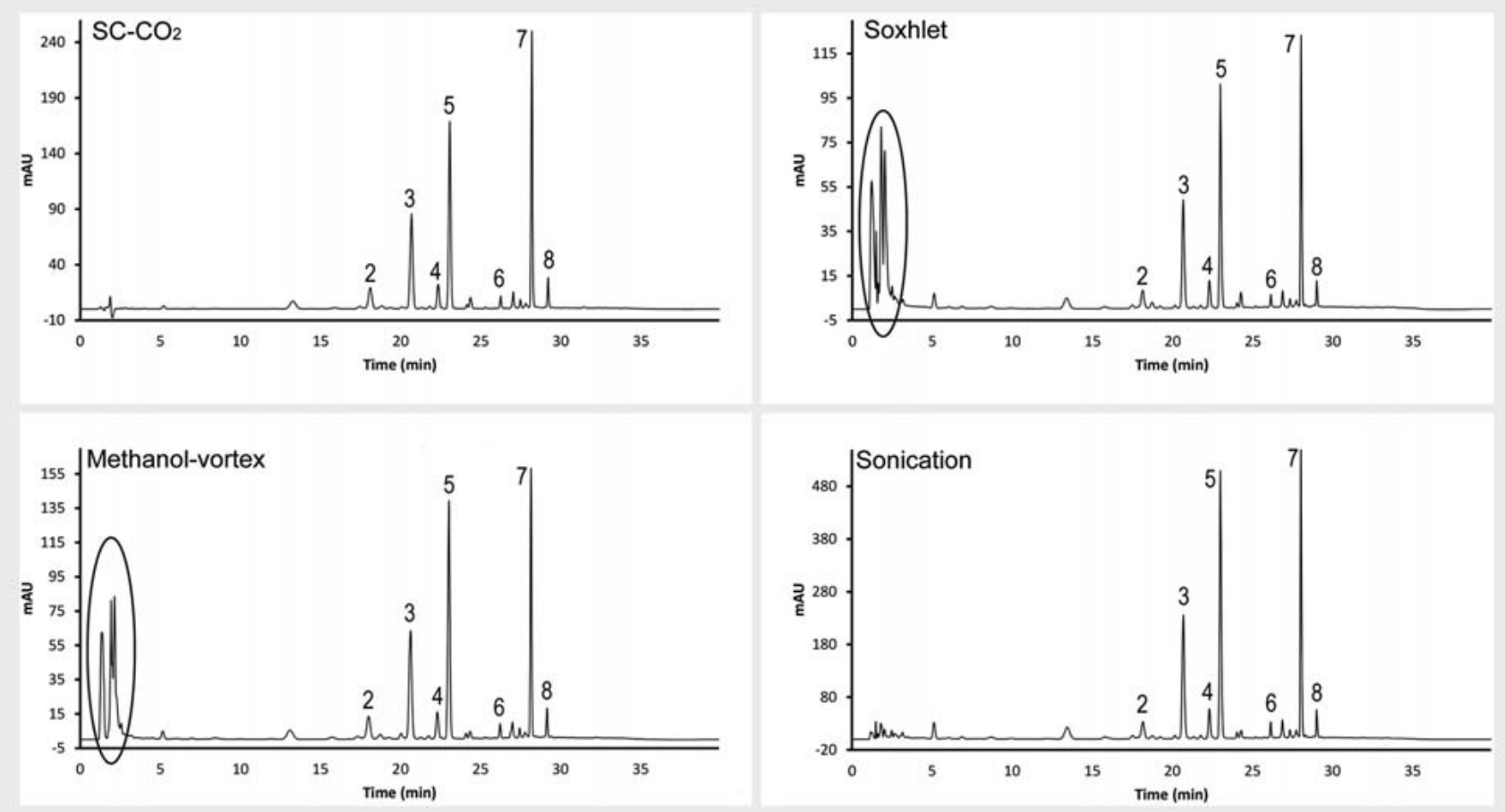

- Fig. 6 HPLC profiles of A. sylvestris root extracted by various extraction methods. The four extraction methods were SC- $\mathrm{CO}_{2}$, Soxhlet, methanol vortex, and sonication (top to bottom). HPLC chromatograms were analyzed at $289 \mathrm{~nm}$. The components were identified by LC-ESI-MS/MS ( $\vee$ Table 1 ). The encircled peaks represent polar components that were only extracted by Soxhlet and the methanol vortex method.

- Table 1 Overview of components found in A. sylvestris roots extracts.

\begin{tabular}{|c|c|c|c|c|}
\hline No & Compound & MW & $\begin{array}{l}\text { Quasi-molecular ions } \\
{\left[\mathrm{M}+\mathrm{NH}_{4}\right]^{+}}\end{array}$ & Fragment ions \\
\hline 1 & Isopicropodophyllone & 412 & 430 & 245, 201 \\
\hline 2 & Podophyllotoxone & 412 & 430 & 245, 201 \\
\hline 3 & Deoxypodophyllotoxin & 398 & 416 & 231,187 \\
\hline 4 & Yatein & 400 & 418 & 223,181 \\
\hline 5 & Anhydropodorhizol & 398 & 416 & 231,135 \\
\hline 6 & Angeloyl podophyllotoxin & 496 & 514 & $397,313,229$ \\
\hline 7 & Anthriscrusin & 388 & 406 & 191 \\
\hline 8 & $\begin{array}{l}\text { 2-methyl-4-[[(2Z)-2-methyl-1-oxo-2-buten-1-yl]oxy]-,(2E)-3-(7-methoxy- } \\
\text { 1,3-benzodioxol-5-yl)-2-propen-1yl ester, 2(Z)-2-butenoic acid }\end{array}$ & 388 & 406 & 191 \\
\hline
\end{tabular}

Compounds 1-5, 7, and 8 were identified by Multiple Reaction Monitoring based on the data of Hendrawati and coworkers [2]. Compound 6 was identified by Product Ion Scan and compared to the data of Koulman and coworkers [3].

2-methyl-4-[[(2Z)-2-methyl-1-oxo-2-buten-1-yl]oxy]-,(2E)-3-(7methoxy-1,3-benzodioxol-5-yl)-2-propen-1yl ester, 2(Z)-2-butenoic acid (8) were detected ( $\vee$ Table 1, Fig. 6, and Fig. 3S, Supporting Information). Identification of the peaks was based on the data of Hendrawati et al. and Koulman et al. [9, 17]. In all four extracts, the fingerprint of these peaks was similar, indicating that all extraction methods are equally capable of extracting lignans present in A. sylvestris roots. The lignans found in this study are structurally related to DPT. The main lignan peaks found were DPT (3) and anhydropodorhizol (5) (peak area, > Fig. 6). Anhydropodorhizol is structurally linked to yatein, which is a precursor of DPT $[23,24]$. Therefore, it could be of interest to increase the DPT yields by pathway engineering aimed at converting anhydropodorhizol to DPT [25]. 
DPT is a precursor of podophyllotoxin, which can be converted to the pharmaceutically important anticancer drugs etoposide and teniposide. Since the natural source of podophyllotoxin, $P$. hexandrum, is endangered in its native habitat, we were interested in the extraction of DPT from A. sylvestris. The $\mathrm{SC}-\mathrm{CO}_{2}$ extraction method has been used to extract lignans from various plant material and components from root material, but has not been described yet for the extraction of DPT from $A$. sylvestris. Furthermore, DPT has not been extracted before from a plant without the addition of a cosolvent. We showed that low volume and DPT-enriched $A$. sylvestris extracts can be obtained by $\mathrm{SC}-\mathrm{CO}_{2}$ extraction. The $\mathrm{SC}-\mathrm{CO}_{2}$ method can be scaled up for industrial application, which has already been done for the decaffeination of coffee and tea [26]. Therefore, the SC- $\mathrm{CO}_{2}$ method has the potential to be used in the future for large-scale extraction of DPT from A. sylvestris. A quick methanol vortex extraction method was developed, which can be used for quantification of the DPT content in $A$. sylvestris roots. This can be convenient for plant breeding programs of $A$. sylvestris aimed at higher DPT production yields. Taken together, this research underscores the importance of A. sylvestris as a novel source for anticancer drugs. Although, further research is necessary to determine if $A$. sylvestris can become a cash crop for farmers.

\section{Materials and Methods}

\section{Plant material}

Roots of A. sylvestris were collected in May 2013 from flowering populations at various locations in the province of Groningen, The Netherlands. The plants were identified by Christel Seegers using the Dutch flora book [27]. Voucher specimens have been deposited in the collection of the University of Groningen; Asylv2013. The roots were collected, rinsed with tap water, and dried overnight at $30^{\circ} \mathrm{C}$. All roots were pooled, cut into pieces, ground, and sieved (1-2.8 $\mathrm{mm})$.

\section{Chemicals}

Technical methanol $(98.5 \%, v / v)$ and acetonitrile $(99.8 \%, v / v)$ were purchased from VWR. Ammonium formate (>97\%, v/v), propidium iodide ( $>94 \%, v / v)$, and the reference compound etoposide ( $\geq 98 \%$ ) were purchased from Sigma-Aldrich. Other chemicals used were methanol absolute AR (99.8\%, v/v; Biosolve), formic acid (98-100\%; Merck), carbon dioxide (99.7\%, v/v; Linde), triton X-100 (Fluka Biochemica), and RNAse A (Qiagen). The cell lines A549 and HeLa were obtained from ATCC. Reference compound DPT [ $>98 \%$ pure, ${ }^{1} \mathrm{H}$ NMR $\left(\mathrm{CDCl}_{3}\right)$ and HPLC-ESI/MS, Fig. 4S, Supporting Information] for HPLC and LC-ESI-MS/MS analysis was isolated from $A$. sylvestris at the Department of Chemical and Pharmaceutical Biology, Groningen, The Netherlands by the method of van Uden [8]. DPT [98\% pure, ${ }^{1} \mathrm{H}$ NMR $\left(\mathrm{CDCl}_{3}\right)$ and HPLC-ESI-MS/MS, Fig. 5S, Supporting Information] for FACS analysis was purchased from Toronto Research Chemicals.

\section{Extraction of deoxypodophyllotoxin from plant roots}

$\mathrm{SC}-\mathrm{CO}_{2}$ extraction as a "green process" was compared with Soxhlet, methanol-vortex, and sonication for extraction of DPT from A. sylvestris roots. Root fragments varying from 1 to $2.8 \mathrm{~mm}$ were used for the extractions.

\section{Supercritical carbon dioxide extraction}

The SC- $\mathrm{CO}_{2}$ extraction method was designed with a future largescale extraction of DPT in mind. The high-pressure setup consists of a stirred batch reactor (Parr Instrument, $100 \mathrm{~mL}$ ), an electrical heating element with temperature controller, a high-pressure pump unit, and a carbon dioxide feeding bottle (Fig. 6S, Supporting Information). The carbon dioxide was supplied to the reactor using a membrane pump (Lewa, capacity $60 \mathrm{~kg} / \mathrm{hr}$, maximum pressure $35 \mathrm{MPa}$ ). To prevent cavitation in the pump, the carbon dioxide was first cooled to $0{ }^{\circ} \mathrm{C}$ in a heat exchanger (Huber). After pressurizing, a second heat exchanger with hot oil was used to heat the carbon dioxide to the desired temperature [28].

For extraction, a spinning basket was filled with $1 \mathrm{~g}$ of plant material and placed on the stirrer in the batch reactor. A heat exchanger was placed around the reactor and the reactor was filled with $\mathrm{CO}_{2}$ until the desired pressure was achieved (between 15 and $42 \mathrm{~g}$ of $\left(\mathrm{CO}_{2}\right)$. The plant material was extracted in a static extraction system for $1 \mathrm{~h}$ at $90 \mathrm{rpm}$. A factorial design was used to establish the most critical parameters: pressure (100, 175, and $250 \mathrm{bar})$ and temperature $\left(40,60\right.$ and $\left.80^{\circ} \mathrm{C}\right)$. After the extraction, the reactor was cooled down to $30^{\circ} \mathrm{C}$ and depressurized. The residue in the reactor was dissolved in methanol and transferred to a $25-\mathrm{mL}$ volumetric flask. The amount of DPT was determined by HPLC using a calibration curve. Samples were stored at $4{ }^{\circ} \mathrm{C}$ before analysis.

\section{Soxhlet extraction}

In the literature, up to now, the report on DPT extraction was by the traditional Soxhlet method [8]. We adjusted the protocol to a small-scale extraction method performed in a Tecator Soxtec System HT2 comprising two 1045 extraction units connected to an oil heating device (1046 service unit; Gemini). One gram of plant material was transferred to a cellulose thimble (FOSS Benelux BV) and extracted three times ( $80 \mathrm{~mL}$ methanol) for $1 \mathrm{~h}$. After every extraction step, the thimble was rinsed with the solvent three times before the beaker was refilled with fresh solvent. The first two extractions were pooled and concentrated, and the volume was adjusted to $100 \mathrm{~mL}$ in a volumetric flask. The volume of the third extraction was concentrated and adjusted to $20 \mathrm{~mL}$. The amount of DPT was determined by HPLC analysis. Samples were stored at $4^{\circ} \mathrm{C}$ before analysis.

\section{Methanol vortex extraction}

For analytic purposes, a quick methanol vortex extraction method was designed for extraction of DPT from A. sylvestris roots. Ten $\mathrm{mL}$ of methanol were added to $1 \mathrm{~g}$ of plant material. The sample was vortexed for 30 s on a Heidolph Reax top, at 2500 rpm (Heidolph), followed by $10 \mathrm{~min}$ of centrifugation $\left(2900 \mathrm{~g}\right.$ and $4{ }^{\circ} \mathrm{C}$ ) to separate the supernatant from the solid fraction. This extraction was repeated four times. The first three supernatants were pooled and the volume was adjusted to $50 \mathrm{~mL}$ in volumetric flasks. The fourth supernatant was kept separate and the volume was adjusted to $25 \mathrm{~mL}$ in a volumetric flask. The DPT concentration was determined by HPLC analysis. Samples were stored at $4^{\circ} \mathrm{C}$ before analysis. 


\section{Sonication}

DPT has been extracted by sonication as described previously [9]. Briefly, $100 \mathrm{mg}$ of dried plant material were weighed into a Sovirel tube. The sample was sonicated for $1 \mathrm{~h}$ in a Brandson 5210 ultrasonic bath (Boom B. V.) after the addition of $2 \mathrm{~mL} 80 \%$ of methanol. Subsequently, $4 \mathrm{~mL}$ of dichloromethane and $4 \mathrm{~mL}$ of water were added. The mixture was vortexed and centrifuged $(1000 \mathrm{~g}$, $5 \mathrm{~min}$ ). The organic layer was transferred to Eppendorf tubes and dried overnight in the fume hood and dissolved in $2 \mathrm{~mL}$ of methanol (volumetric flask). The amount of DPT was determined by HPLC. Samples were stored at $4^{\circ} \mathrm{C}$ before analysis.

\section{Assessment of deoxypodophyllotoxin amount by HPLC}

The amount of DPT was analyzed by HPLC as previously described [29], with some modifications. A Shimadzu-VP system was used, consisting of an LC-10AT pump, SIL-20A autosampler, and diode array detector SPD-M10A. A Zorbax Eclipse XDB-C18 column $(4.6 \times 150 \mathrm{~mm} ; 5 \mu \mathrm{m}$; Agilent) and an Eclipse XDB-C18 guard column containing cartridges (4.6 id. $\times 12.5 \mathrm{~mm}, 5 \mu \mathrm{m}$; Agilent) were used for the analysis. The mobile phase consisted of water/ acetonitrile (95:5) (A) and acetonitrile/water (95:5) (B), both supplemented with $0.1 \%$ formic acid and $2 \mathrm{mM}$ ammonium formate. The elution flow rate was $1 \mathrm{~mL} / \mathrm{min}$ and the column temperature was held constant at $25^{\circ} \mathrm{C}$. The injection volume for the standard and extracts was $20 \mu \mathrm{L}$. A gradient program was performed that consisted of gradient buffer A-B: $10 \mathrm{~min} 70: 30(\mathrm{v} / \mathrm{v})$ isocratic; gradient 8 min 50:50 (v/v); gradient 7 min 10:90 (v/v); $5 \mathrm{~min} 10: 90(\mathrm{v} / \mathrm{v})$ isocratic; gradient $5 \mathrm{~min} 70: 30(\mathrm{v} / \mathrm{v}) ; 5 \mathrm{~min}$ $70: 30(\mathrm{v} / \mathrm{v})$ isocratic. The HPLC method was able to separate DPT from the other compounds. The extracts were diluted in methanol (see Extraction section) to obtain DPT concentrations within the range of the calibration curve. The procedure was validated according to ICH guidelines [30]. Evaluation of linearity, limit of detection (LOD), limit of quantification (LOQ), precision, and accuracy are presented in Table 1S, Supporting Information.

\section{Identification of deoxypodophyllotoxin by LC-ESI-MS/MS}

The presence of DPT and related lignans in the extracts was confirmed by LC-ESI-MS/MS. The analysis was performed using a Shimadzu LC system consisting of 2 LC-20AD gradient pumps and a SIL-20AC autosampler. The LC system was coupled to an API 3000 triple quadrupole mass spectrometer (Applied Biosystems/MDS Sciex) via a TurbolonSpray source. Data were collected and analyzed by Analyst 1.5.2 acquisition software (Applied Biosystems/ MDS Sciex). An Alltima C18 (Grace Davision) narrow-bore guard column $(2.1 \times 150 \mathrm{~mm}, 5 \mu \mathrm{m})$ was used. Buffers and the gradient program were the same as for HPLC analysis. The ionization was performed by electrospray in the positive mode $\left[\left(\mathrm{M}+\mathrm{NH}_{4}\right)^{+}\right.$adduct ions]. The source temperature was set to $450^{\circ} \mathrm{C}$. The instrument was operated with an ionspray voltage of $5.2 \mathrm{kV}$. Nitrogen was used for both the curtain gas and nebulizing gas. Full scan mass spectra were acquired at a scan rate of $1 \mathrm{scan} / 4 \mathrm{sec}$ with a scan range of 100-1400 amu and a step size of $0.1 \mathrm{amu}$.

\section{Analysis of cell cycle by flow cytometry}

Cell cycle arrest was studied in A549 and HeLa cells by FACS. A549 cells were cultivated in DMEM/F12 media and HeLa cells in DMEM media. Both media were supplemented with $10 \%$ fetal calf serum, 100 units $/ \mathrm{mL}$ penicillin, and $100 \mu \mathrm{g} / \mathrm{mL}$ streptomycin. The cell lines were cultivated in a humidified incubator at $37^{\circ} \mathrm{C}$ containing $5 \% \mathrm{CO}_{2}$. One million cells were seeded in 6-well plates and treated with different concentrations of SC-CO $\mathrm{CO}_{2}$ extract, pure DPT, or etoposide $(0,0.1,0.5,1$, and $10 \mu \mathrm{M})$ for $24 \mathrm{~h}$. Cells were fixated in $70 \%$ ice-cold ethanol and stained in $300 \mu \mathrm{L}$ propidium iodide solution [1\% (v/v) Triton X-100, $200 \mu \mathrm{g} / \mathrm{mL}$ RNase A, and $20 \mu \mathrm{g} / \mathrm{mL}$ propidium iodide]. The DNA contents of 20000 events were measured by flow cytometer (Becton Dickinson). Histograms were analyzed using Modfit LT 4.1 software.

\section{Statistics}

Statistical analysis was performed with SPSS 23 software. Comparative statistical analysis of the groups was performed using Student's t-test $(n=6)$. The lines in $\boldsymbol{\sim}$ Figs. 2 and $\mathbf{5}$ represent the mean. The values in the text are reported as the mean \pm SD. $P$ values $<0.05$ were considered significant.

\section{Supporting information}

HPLC validation, HPLC profile Soxhlet extract of $\mathrm{SC}-\mathrm{CO}_{2}$ extracted roots, cell cycle arrest of HeLa cells, chemical structure of compounds $1-8$, and the experimental setup are available as Supporting Information.

\section{Acknowledgements}

The authors thank H.J. Heeres and M. H. de Vries of the Department of Engineering and Technology of the University of Groningen for the usage of the supercritical carbon dioxide equipment. The authors thank C. M. Jeronimus-Stratingh of the Mass Spectrometry Core Facility of the University of Groningen for the LC-ESI-MS/MS analysis. This work was supported by EU regional funding and The PhytoSana project in the INTERREG IV A Deutschland-Nederland program: 34- INTERREG IV A $\mathrm{I}-1-01=193$.

\section{Conflict of Interest}

The authors declare no conflict of interest.

\section{References}

[1] CITES. Convention of international trade in endangered species of wild fauna and flora. 2015. Available at www.cites.org/. Accessed December 15, 2017

[2] van Mierlo JEM, van Groenendael JM. A population dynamic approach to the control of Anthriscus sylvestris (L.) Hoffm. J Appl Ecol 1991; 28: 128139

[3] Hansson ML, Persson TS. Anthriscus sylvestris - a growing conservation problem? Ann Bot Fenn 1994; 31: 205-213

[4] Magnússon SH. NOBANIS-invasive alien species fact sheet - Anthriscus sylvestris. 2011. Available at www.nobanis.org/. Accessed December 15, 2017

[5] Sun Y], Li ZL, Chen H, Liu XQ, Zhou W, Hua HM. Three new cytotoxic aryltetralin lignans from Sinopodophyllum emodi. Bioorg Med Chem Lett 2011; $21: 3794-3797$ 
[6] Vasilev NP, Julsing MK, Koulman A, Clarkson C, Woerdenbag H], Ionkova I, Bos R, Jaroszewski JW, Kayser O, Quax WJ. Bioconversion of deoxypodophyllotoxin into epipodophyllotoxin in $E$. coli using human cytochrome P450 3A4. J Biotechnol 2006; 126: 383-393

[7] Yamaguchi H, Arimoto M, Nakajima S, Tanoguchi M, Fukada Y. Studies on the constituents of the seeds of Hernandia ovigera L. V.: Syntheses of epipodophyllotoxin and podophyllotoxin from desoxypodophyllotoxin. Chem Pharm Bull (Tokyo) 1986; 34: 2056-2060

[8] Van Uden W, Bos JA, Boeke GM, Woerdenbag HJ, Pras N. The large-scale isolation of deoxypodophyllotoxin from rhizomes of Anthriscus sylvestris followed by its bioconversion into 5-methoxypodophyllotoxin $\beta$-D-glucoside by cell cultures of Linum flavum. J Nat Prod 1997; 60: 401-403

[9] Koulman A, Kubbinga ME, Batterman S, Woerdenbag H], Pras N, Woolley JG, Quax WJ. A phytochemical study of lignans in whole plants and cell suspension cultures of Anthriscus sylvestris. Planta Med 2003; 69: 733738

[10] Visscher G. Some observations about major chemical accidents from recent CBS investigations. iChemE 2008; 54: 1-15

[11] Anastas P, Eghbali N. Green chemistry: principles and practice. Chem Soc Rev 2010; 39: 301-312

[12] Reverchon E, De Marco I. Supercritical fluid extraction and fractionation of natural matter. J Supercrit Fluids 2006; 38: 146-166

[13] Wang L, Weller CL. Recent advances in extraction of nutraceuticals from plants. Trends Food Sci Technol 2006; 17: 300-312

[14] Kim Y, Choi YH, Chin YW, Jang YP, Kim YC, Kim J, Kim JY, Joung SN, Noh MJ, Yoo KP. Effect of plant matrix and fluid ethanol concentration on supercritical fluid extraction efficiency of Schisandrin derivatives. J Chromatogr Sci 1999; 37: 457-461

[15] Lojková L, Slanina J, Mikešová M, Táborská E, Vejrosta J. Supercritical fluid extraction of lignans from seeds and leaves of Schizandra chinensis. Phytochem Anal 1997; 8: 261-265

[16] Gupta DK, Verma MK, Lal S, Anand R, Khajuria RK, Kitchlu S, Koul S. Extraction studies of Podophyllum hexandrum using conventional and nonconventional methods by HPLC-UV-DAD. J Liq Chromatogr Relat Technol 2013; 37: 259-273

[17] Hendrawati O, Woerdenbag HJ, Michiels PJA, Aantjes HG, van Dam A, Kayser O. Identification of lignans and related compounds in Anthriscus sylvestris by LC-ESI-MS/MS and LC-SPE-NMR. Phytochemistry 2011; 72: 2172-2179

[18] Yong Y, Shin SY, Lee YH, Lim Y. Antitumor activity of deoxypodophyllotoxin isolated from Anthriscus sylvestris: Induction of G2/M cell cycle arrest and caspase-dependent apoptosis. Bioorg Med Chem Lett 2009; 19 : 4367-4371

[19] Hainsworth JD, Greco FA. Etoposide: twenty years later. Ann Oncol 1995; 6: 325-341

[20] Guerram M, Jiang ZZ, Zhang LY. Podophyllotoxin, a medicinal agent of plant origin: past, present and future. Chin J Nat Med 2012; 10: 161-169

[21] Wang YR, Xu Y, Jiang ZZ, Guerram M, Wang B, Zhu X, Zhang LY. Deoxypodophyllotoxin induces G2/M cell cycle arrest and apoptosis in SGC7901 cells and inhibits tumor growth in vivo. Molecules 2015; 20: 1661-1675

[22] Imbert TF. Discovery of podophyllotoxins. Biochimie 1998; 80: 207-222

[23] Kamil WM, Dewick PM. Biosynthetic relationship of aryltetralin lactone lignans to dibenzylbutyrolactone lignans. Phytochemistry 1986; 25: 2093-2102

[24] Lau W, Sattely ES. Six enzymes from mayapple that complete the biosynthetic pathway to the etoposide aglycone. Science 2015; 349: 12241228

[25] Seegers CLC, Setroikromo R, Quax W]. Towards metabolic engineering of podophyllotoxin production. InTech 2017. doi:10.5772/67615

[26] King M, Bott T. Extraction of natural Products using near-critical Solvents. Dordrecht: Springer Netherlands; 1993

[27] van der Meijden R, Weeda EJ, Adema FAC, de Joncheere G]. Heukels Flora van Nederland. Groningen: Wolters-Noordhoff; 1983

[28] Muljana H, Picchioni F, Heeres H], Janssen LPBM. Process-product studies on starch acetylation reactions in pressurised carbon dioxide. Starch 2010; 62: 566-576

[29] Hendrawati O, Woerdenbag HJ, Hille J, Quax W], Kayser O. Seasonal variations in the deoxypodophyllotoxin content and yield of Anthriscus sylvestris L. (Hoffm.) grown in the field and under controlled conditions. J Agric Food Chem 2011; 59: 8132-8139

[30] ICH. Guideline: Validation of analytical Procedures: Text and Methodology, Q2(R1). Geneva: ICH; 2005: 1 